\title{
Cluster Integration Path Analysis to Model PT Pelindo II's Market Mapping
}

\author{
Solimun*, Adji Achmad Rinaldo Fernandes, Intan Rahmawati, Riyanti Isaskar, Lailil Muflikhah, \\ Fathiyatul Laili Nur Rasyidah \\ Brawijaya University \\ St. Veteran, Malang 65145 East Java \\ Indonesia
}

Received: June 18, 2021. Received: November 30, 2021. Accepted: December 20, 2021. Published: December 31, 2021.

\begin{abstract}
This research aims to estimate the path analysis function of cluster integration to model the market mapping of PT Pelindo II. The population of this research is all companies or communities that cooperate with PT Pelindo II. The sample in this study is part of the community companies that cooperate with PT Pelindo II. This study also uses a survey method with a questionnaire. The sampling method used is purposive sampling. After getting data from the questionnaire, the next step is to perform cluster analysis. After performing cluster analysis, modeling is carried out using Path analysis. Path analysis in Cluster 1 and Cluster 1 shows that from nine direct effect tests, it was found that 2 effects gave significant results and the rest did not give significant effects. The significant effect is the influence of Customer Engagement (X3) on Company Potential (Y1). The coefficient of determination for the total path analysis in Cluster 1 is $\mathbf{0 . 8 2 3 5}$ or $\mathbf{8 2 . 3 5 \%}$, while in Cluster 2 it is 0.7421 or $74.21 \%$. Novelty in this research is Cluster integration modeling with Path. This study develops Cluster and Path analysis, where many previous studies only use Cluster analysis or Path analysis but are not integrated.
\end{abstract}

Key-Words: Path analysis, Cluster Analysis, Company potential, Company productivity, Market Mapping, Pelindo II

\section{INTRODUCTION}

STATISTICS is a method and science about collecting, processing, presenting, analyzing data, and how to draw general and informative conclusions with a series of procedures both descriptively and inferentially. According to [1], regression analysis is related to the study of the dependence of one variable, namely the dependent variable, on one or more other variables, namely the independent variable, to estimate the average value (population) of the dependent variable from the value of the dependent variable. known or fixed value of the independent variable (in repeated sampling). Regression analysis is used if you want to know whether the independent variable has a direct influence on the dependent variable. The regression analysis approach can be done in three ways, namely parametric approach, semiparametric approach, and nonparametric approach.

Path analysis was first developed by Wright in 1934 [2]. Path analysis is used to test the model of the relationship between variables in the form of cause and effect [3]. Path analysis is a technique that can be used to determine whether there is a causal relationship between exogenous variables and endogenous variables. Path analysis is not only used to determine the direct effect of exogenous variables on endogenous variables, but also explains whether or not there is an indirect effect given by exogenous variables on endogenous variables through mediating endogenous variables.

Identification of the target market is the main step needed by the company in planning and developing marketing strategies. The marketing success of a product is largely determined by the suitability of the product with the needs of consumers in certain segments, considering that consumers are always faced with many choices. Global technological developments continue to increase significantly. Big Data is a collection of data that has been stored both structured and unstructured and stored traditionally or digitally which has great potential to maximize the information to be obtained.

PT Pelabuhan Indonesia II (Persero) or often known as Pelindo II is a State-Owned Enterprise engaged in logistics, specifically in port management and development. In order to compete more effectively, seeing the condition of PT Pelabuhan Indonesia II (Persero) which is a large company that has a wide variety of customers, especially business to business, this requires PT Pelabuhan Indonesia II (Persero) to segment the market. The need to segment the PT Pelindo II market is getting stronger with the construction of the Kra Canal (Kra Canal) in Thailand, which has the potential to kill the maritime economy in Indonesia.

Segmentation efforts can bring business to business benefits to use the resources they have appropriately, segmentation also has an important role to limit to get the right focus by selecting target consumers so that it can bring competitive advantage for business to business. Based on the explanation above, the research aims to model the integration of Clusters with Path. Where cluster integration is very rarely done in market mapping. Integration in this case means that after conducting a cluster analysis, several groups will be obtained, then each of these groups will be carried out a path analysis to find out what factors can increase company productivity. 


\section{LITERATURE REVIEW}

\section{A. Parametric Regression Analysis}

Regression analysis according to [4] is a statistical methodology that utilizes the relationship between two or more quantitative variables so that the response variable or outcome can be predicted from other variables. Simple linear regression analysis can be used when one predictor variable is used to predict the response variable. The simple linear regression model can be expressed as follows:

$$
Y_{i}=\beta_{0}+\beta_{1} X_{i}+\varepsilon_{i}
$$

with:

$\mathrm{Y}_{\mathrm{i}} \quad$ : the value of the response variable on the $\mathrm{i}$-th observation

$\beta_{0} \quad$ : intercept parameter

$\beta_{1} \quad$ : slope parameter

$\mathrm{X}_{\mathrm{i}} \quad$ : the value of the predictor variable on the $\mathrm{i}$-th observation

$\varepsilon_{\mathrm{i}} \quad$ : error on observation $\mathrm{i}$

If there is more than one predictor variable, multiple linear regression analysis is used. According to [4] multiple linear regression analysis is one of the most widely used statistical methods when there is more than one predictor variable used to predict the response variable. Multiple linear regression models can be expressed as follows:

$$
Y_{i}=\beta_{0}+\beta_{1} X_{i 1}+\beta_{2} X_{i 2}+\varepsilon_{i}
$$
follows:

The general linear regression model can be expressed as

$$
Y_{i}=\beta_{0}+\beta_{1} X_{i 1}+\beta_{2} X_{i 2}+\cdots+\beta_{p} X_{i p-1}+\varepsilon_{i}
$$

with:

$$
\begin{array}{ll}
\mathrm{Y}_{\mathrm{i}} & : \text { the value of the response variable on the } \mathrm{i}- \\
\text { th observation } & \\
\beta_{0} & : \text { intercept parameter } \\
\beta_{11}, \beta_{2, \ldots, \beta_{\mathrm{p}}} & : \text { slope parameters } \\
\mathrm{X}_{\mathrm{i} 1, \ldots, \mathrm{X}_{\mathrm{ip}-1}} & : \text { nilai variabel prediktor dalam pengamatan } \\
\mathrm{ke}-\mathrm{i} . & : 1,2, \ldots, \mathrm{n} . \\
\mathrm{i} & : \text { number of observations } \\
\mathrm{n} & : \text { error on observation } \mathrm{i}
\end{array}
$$

Solving the problem of parameter estimation in multiple linear regression analysis that has more than two predictor variables can be solved by the matrix method. Equation 2.3 is a general equation of the population multiple linear regression model with the number of predictor variables as many as $p-1$ pieces. If there are $\mathrm{n}$ observations and $\mathrm{p}$ predictor variables, the regression equation can be written as follows:

$$
\begin{aligned}
& Y_{1}=\beta_{0}+\beta_{1} X_{11}+\beta_{2} X_{12}+\cdots+\beta_{p} X_{1 p-1}+\varepsilon_{1} \\
& Y_{2}=\beta_{0}+\beta_{1} X_{21}+\beta_{2} X_{22}+\cdots+\beta_{p} X_{2 p-1}+\varepsilon_{2} \\
& Y_{3}=\beta_{0}+\beta_{1} X_{31}+\beta_{2} X_{32}+\cdots+\beta_{p} X_{3 p-1}+\varepsilon_{3} \\
& \vdots \quad \vdots \quad \vdots \quad \vdots \quad \vdots \quad \vdots \\
& Y_{n}=\beta_{0}+\beta_{1} X_{n 1}+\beta_{2} X_{n 2}+\cdots+\beta_{p} X_{n p-1}+\varepsilon_{n}
\end{aligned}
$$

From the above equation, it can be written in matrix form as follows:

$$
\left(\begin{array}{c}
Y_{1} \\
Y_{2} \\
Y_{3} \\
\vdots \\
Y_{n}
\end{array}\right)=\left(\begin{array}{ccccc}
1 & X_{11} & X_{12} & \cdots & X_{1 p-1} \\
1 & X_{21} & X_{22} & \cdots & X_{2 p-1} \\
1 & X_{31} & X_{32} & \cdots & X_{3 p-1} \\
\vdots & \vdots & \vdots & \ddots & \vdots \\
1 & X_{n 1} & X_{n 2} & \cdots & X_{n p-1}
\end{array}\right)+\left(\begin{array}{c}
\varepsilon_{1} \\
\varepsilon_{2} \\
\varepsilon_{3} \\
\vdots \\
\varepsilon_{n}
\end{array}\right)
$$

The linear regression model in matrix form can be written as follows:

$$
\underset{\sim}{Y}=\mathbf{X} \underset{\sim}{\beta}+\underset{\sim}{\varepsilon}
$$

Parameter estimation in the parametric regression model with a matrix approach is done by minimizing the number of squares of errors

$$
\begin{aligned}
& \underset{\sim}{\mathcal{E}}=\underset{\sim}{Y}-\mathbf{X} \underset{\sim}{\beta} \\
& \underset{\sim}{\underset{\varepsilon}{\varepsilon}} \underset{\sim}{\mathcal{E}}=(\underset{\sim}{Y}-\underset{\sim}{\mathbf{X}})^{\prime}(\underset{\sim}{Y}-\mathbf{X} \underset{\sim}{\beta})
\end{aligned}
$$

Then it is derived to the parameter, namely $\beta$ and equates to zero

$$
\begin{aligned}
& \underset{\sim}{\mathcal{E}} \underset{\sim}{\mathcal{E}}=\underset{\sim}{Y_{\sim}^{\prime}} \underset{\sim}{Y}-\underset{\sim}{Y^{\prime}} \underset{\sim}{\beta \mathbf{X}}-{\underset{\sim}{\beta}}^{\prime} \mathbf{X}^{\prime} Y+\underset{\sim}{\beta} \mathbf{X}^{\prime} \mathbf{X} \underset{\sim}{\beta} \\
& \underset{\sim}{\mathcal{E}} \underset{\sim}{\mathcal{E}}=\underset{\sim}{Y^{\prime}} \underset{\sim}{Y}-2 \underset{\sim}{\beta} \mathbf{X}^{\prime} Y+\left(\mathbf{X}^{\prime} \mathbf{X}\right) \underset{\sim}{\beta^{2}}
\end{aligned}
$$

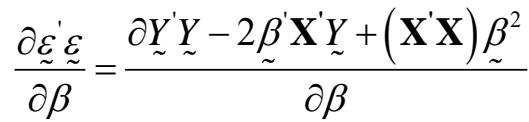

$$
\begin{aligned}
& \frac{\partial \tilde{\sim}_{\tilde{\mathcal{E}}}^{\mathcal{E}}}{\partial \beta}=0-2 \mathbf{X}^{\prime} \underset{\sim}{\boldsymbol{\gamma}}+2\left(\mathbf{X}^{\prime} \mathbf{X}\right) \underset{\sim}{\beta} \\
& 0=0-2 \mathbf{X}^{\prime} \underset{\sim}{Y}+2\left(\mathbf{X}^{\prime} \mathbf{X}\right) \underset{\sim}{\hat{\beta}} \\
& 2\left(\mathbf{X}^{\prime} \mathbf{X}\right) \underset{\sim}{\hat{\beta}}=2 \mathbf{X}^{\prime} \underset{\sim}{Y} \\
& \left(\mathbf{X}^{\prime} \mathbf{X}\right) \underset{\sim}{\hat{\beta}}=\mathbf{X}^{\prime} \underset{\sim}{Y} \\
& \left(\mathbf{X}^{\prime} \mathbf{X}\right)^{-1}\left(\mathbf{X}^{\prime} \mathbf{X}\right) \underset{\sim}{\hat{\beta}}=\left(\mathbf{X}^{\prime} \mathbf{X}\right)^{-1} \mathbf{X}^{\prime} \underset{\sim}{\boldsymbol{\gamma}} \\
& \mathbf{I} \hat{\sim}=\left(\mathbf{X}^{\prime} \mathbf{X}\right)^{-1} \mathbf{X}_{\sim}^{\prime} \underset{\sim}{Y}
\end{aligned}
$$

So that the parameter estimation for multiple linear regression with a matrix approach is as follows:

$$
\underset{\sim}{\hat{\beta}}=\left(\mathbf{X}^{\prime} \mathbf{X}\right)^{-1} \mathbf{X}^{\prime} \underset{\sim}{Y}
$$

\section{B. Path Analysis}

Path analysis was first developed in 1934 by a geneticist, Sewall Wright. Path analysis is a technique for estimating the effect of a set of independent variables on the dependent variable from a series of observed correlations. The purpose of path analysis is to measure the direct effect on each separate path in the system thereby finding out the extent to which the variation of a given effect can be determined by each cause. [5] describes six assumptions that underlie path analysis, namely:

1) The relationship between variables is linear and additive.

2) The error is normally distributed (remaining normality). 
3) The pattern of relationship between variables is recursive

4) Minimum endogenous variable in interval measuring scale.

5) Research variables were measured without error (valid and reliable research instrument).

6) The analyzed model is specified based on the relevant theories and concepts.

The assumption that can make the model change is the assumption of linearity. The assumption of linearity has an influence on the shape of the model. If the linearity assumption is met, then the path analysis is parametric, but if the linearity assumption is not met there are 2 possibilities, if the nonlinear form is known, then use nonlinear path analysis, if the nonlinear form is unknown and there is no information about the data pattern, then use nonparametric path analysis [6][7].

Designing models based on theories and concepts. Theoretically, the relationship between variables can be described in a path diagram or equation to form a structural model. In this study, the equations used to form a structural model are:

$$
\begin{aligned}
& Y_{1}=\beta_{10}+\beta_{11} X_{1}+\beta_{12} X_{2}+\beta_{13} X_{3}+\varepsilon_{1} \\
& Y_{2}=\beta_{20}+\beta_{21} X_{1}+\beta_{22} X_{2}+\beta_{23} X_{3}+\beta_{24} Y_{1}+\varepsilon_{2}
\end{aligned}
$$

In the study, standardization of the predictor variables was carried out with the aim that the units of each predictor variable were the same, in other words the units of the variables would be omitted. [8] standardization (standardize) is done by standard normal transformation with an average of 0 and a variance of 1 , can use the formula:

$Z_{X i}=\frac{x_{j i}-\bar{x}_{j .}}{s_{x_{j}}} \quad Z_{Y i}=\frac{y_{i}-\bar{y}}{s_{y}}$

where:

$Z_{x i} \quad$ : value of the $\mathrm{j}$-th exogenous variable on the standardized i-th observation

$x_{j i} \quad:$ the value of the $\mathrm{j}$-th exogenous variable on the $\mathrm{i}$-th observation

$\bar{x}_{j} \quad$ : the average of the $\mathrm{jth}$ exogenous variables

$S_{x j}$ : the standard deviation of the $\mathrm{j}$-th exogenous variable

$Z_{Y i} \quad:$ the value of the i-observation on the standardized endogenous variable

$y_{i} \quad:$ the value of the i-th observation on the endogenous variable

$\bar{y} \quad:$ the average of endogenous variables

$S_{y} \quad:$ the standard deviation of endogenous variables

$i: 1,2, \ldots, n$

$j: 1,2, \ldots, p$

The formula for the standard deviation of exogenous and endogenous variables can be seen in equation (12).

$s_{x_{j}}=\sqrt{\frac{\sum_{i=1}^{n}\left(x_{j i}-\bar{x}_{j .}\right)^{2}}{n-1}} \quad s_{y}=\sqrt{\frac{\sum_{i=1}^{n}\left(y_{i}-\bar{y}\right)^{2}}{n-1}}$
Equation (9) and equation (10) which have been standardized can be seen in equation (13) and equation (14).

$$
\begin{aligned}
& Z_{Y_{1}}=\beta_{10}+\beta_{11} Z_{X_{1}}+\beta_{12} Z_{X_{2}}+\beta_{13} Z_{X_{3}}+\varepsilon_{1} \\
& Z_{Y_{2}}=\beta_{20}+\beta_{21} Z_{X_{1}}+\beta_{22} Z_{X_{2}}+\beta_{23} Z_{X_{3}}+\beta_{24} Z_{Y_{1}}+\varepsilon_{2}
\end{aligned}
$$

\section{Cluster Analysis}

One approach that can be used in Cluster analysis (group analysis) is an analytical method that aims to group objects into several groups, objects in groups are homogeneous (same) while other group members are heterogeneous (different) [9][10].

The procedure for group formation in Cluster analysis is divided into two, namely hierarchical and non-hierarchical methods. Grouping with the hierarchical method is used when there is no information about the number of clusters. The main principle of the hierarchical method is to group objects that have something in common with one group. While the nonhierarchical method is used when information about the number of clusters is known or has been determined [11].

In the hierarchical grouping method, we start by grouping two or more objects that have something in common. Then, the process continues by passing to another object that has second proximity [12]. And so on so that a tree is obtained where there is a hierarchy or level from the most similar to the most different [12][13]. This tree can provide more clarity in the grouping process or what is commonly called a dendrogram

\section{MethodOLOGY}

The data used in this study is primary data. Primary The population of this research is all companies or communities that cooperate with PT Pelindo II. The sample is part of the population that can represent the population (representative) so that the sample in this study is part of a community company that cooperates with PT Pelindo II. This study also uses a survey method with the research instrument used is a questionnaire, namely the research respondents are directors/managers at each company and the public who have collaborated with PT Pelindo II. The sampling method used is purposive sampling, namely with the criteria of companies or communities that have collaborated with PT Pelindo II. Measurement of variables using the average score of each item. This method uses the average scale of all indicators on each variable so that the average scale data is obtained which is the data of the relevant latent variable. After getting data from the questionnaire, the next step is to perform cluster analysis. The results of the cluster analysis are several groups that can explain the marketing characteristics of PT Pelindo II. The group formed from the Cluster analysis is used as a dummy variable. After performing cluster analysis, modeling is carried out using Path analysis. 


\section{RESULT AND DISCUSSION}

\section{A. Cluster Analysis}

The survey was conducted on 80 consumers of PT Pelindo II using research instruments that had been prepared previously. After the research data was collected, cluster analysis was carried out to determine the market segment of PT Pelindo II. The method used is K-means cluster analysis. The results of the analysis show that the optimal number of clusters is 2, as shown in Figure 1 below.

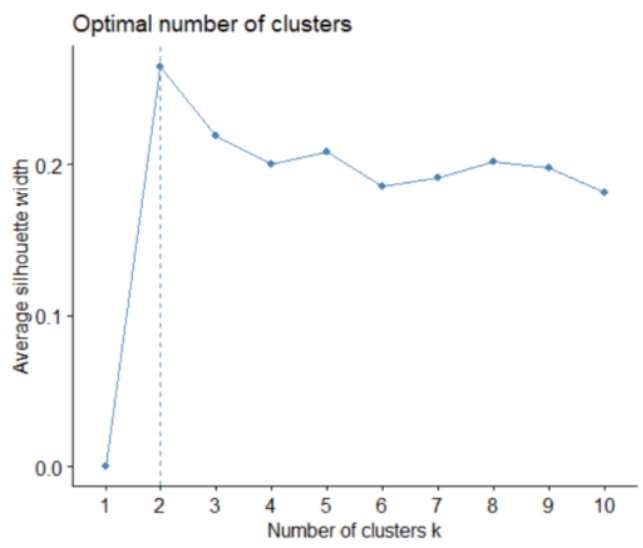

Fig. 1 Number of Optimal Clusters

Based on the results in Figure 1, then the consumers at PT Pelindo II are divided into two based on the research variables, as presented in Table 1 and Figure 1 below.

Table 1. Cluster Characteristics

\begin{tabular}{|c|l|c|c|c|}
\hline No & \multicolumn{1}{|c|}{ Information } & $\begin{array}{c}\text { Over } \\
\text { all }\end{array}$ & $\begin{array}{c}\text { Cluste } \\
\text { r 1 }\end{array}$ & $\begin{array}{c}\text { Cluste } \\
\text { r 2 }\end{array}$ \\
\hline 1 & Many members & 80 & 33 & 47 \\
\hline 2 & Percentage of many members & $100 \%$ & $\begin{array}{c}41.25 \\
\%\end{array}$ & $\begin{array}{c}58.75 \\
\%\end{array}$ \\
\hline 3 & $\begin{array}{l}\text { Average Company Economic } \\
\text { Condition (X1) }\end{array}$ & 3.902 & 3.753 & 4.007 \\
\hline 4 & $\begin{array}{l}\text { Average Quality of Science and } \\
\text { Technology (X2) }\end{array}$ & 3.913 & 3.374 & 4.291 \\
\hline 5 & $\begin{array}{l}\text { Average Customer Engagement } \\
\text { (X3) }\end{array}$ & 3.843 & 3.775 & 3.890 \\
\hline 6 & Average Company Potential (Y1) & 3.848 & 3.293 & 4.238 \\
\hline 8 & $\begin{array}{l}\text { Average Company Productivity } \\
\text { (Y2) }\end{array}$ & 3.825 & 3.697 & 3.915 \\
\hline
\end{tabular}

(Source: processed by researchers, 2021)

\section{B. Assumption Test}

\section{1) Linearity Assumption}

$H_{0}: f(X)$ is a linear function of $\mathrm{X}$ or linear model

$H_{1}: f(X)$ is a non-linear function of $\mathrm{X}$ or a nonlinear model

$\alpha=0.05$

The results of the linearity test for each relationship are shown in table 2 below:
Table 2. Linearity Test Results

\begin{tabular}{|c|c|c|}
\hline Variable & P-Value & $\begin{array}{c}\text { Relationship } \\
\text { between variables }\end{array}$ \\
\hline$X_{1}$ with $Y_{1}$ & 0.6180 & Linear \\
\hline$X_{2}$ with $Y_{1}$ & 0.7888 & Linear \\
\hline$X_{3}$ with $Y_{1}$ & 0.2429 & Linear \\
\hline$X_{1}$ with $Y_{2}$ & 0.4145 & Linear \\
\hline$X_{2}$ with $Y_{2}$ & 0.8158 & Linear \\
\hline$X_{3}$ with $Y_{2}$ & 0.9016 & Linear \\
\hline$Y_{1}$ with $Y_{2}$ & 0.9643 & Linear \\
\hline
\end{tabular}

(Source: processed by researchers, 2021)

Based on Table 2, it can be seen that the relationship between exogenous and endogenous variables produces the value of $p>\alpha=0.05$ so the decision to accept $\mathrm{H}_{0}$ means that the relationship between variables is linear.

\section{2) Normality Assumption}

The normality test was carried out on the structural model residuals which were formed based on the path diagram model concept. The normality test was carried out using the Shapiro Wilk test with the help of $\mathrm{R}$ software. The normality assumption test process is as follows.

$\mathrm{H}_{0}$ : Residual spread normally

$\mathrm{H}_{1}$ : Residual spread abnormally

$\alpha=0.05$

The results of the normality assumption test are shown in Table 3.

Tabel 3. Hasil Output Uji Asumsi Normalitas

\begin{tabular}{|l|l|l|}
\hline \multicolumn{1}{|c|}{ Model } & \multicolumn{1}{|c|}{ P-value } & \multicolumn{1}{c|}{ Decision } \\
\hline $\mathrm{Y} 1 \sim \mathrm{X} 1+\mathrm{X} 2+\mathrm{X} 3$ & 0.0134 & Reject $\mathrm{H}_{0}$ \\
\hline $\mathrm{Y} 3 \sim \mathrm{X} 1+\mathrm{X} 2+\mathrm{X} 3+\mathrm{Y} 1$ & 0.5191 & Accept $\mathrm{H}_{0}$ \\
\hline
\end{tabular}

(Source: processed by researchers, 2021)

Based on the test results, with a significance level of $5 \%$, there is sufficient evidence to state that the structural model 2 and structural model 3 are normally distributed or meet the assumption of normality, while the structural model 1 has residuals that are not normally distributed.

\section{3)Homoscedasticity Assumption}

The homoscedasticity test was carried out using the Breusch Pagan test with the help of $\mathrm{R}$ software. The process of testing the homoscedasticity assumption is as follows.

$\mathrm{H}_{0}$ : There are no symptoms of heteroscedasticity

$\mathrm{H}_{1}$ : There are symptoms of heteroscedasticity

$\alpha=0.05$

The results of the homoscedasticity assumption test are shown in Table 4. 
Table 4. Results of Normality Assumption Test Output

\begin{tabular}{|l|l|l|}
\hline \multicolumn{1}{|c|}{ Model } & \multicolumn{1}{|c|}{ P-value } & \multicolumn{1}{c|}{ Decision } \\
\hline $\mathrm{Y} 1 \sim \mathrm{X} 1+\mathrm{X} 2+\mathrm{X} 3$ & 0.3267 & Accept $\mathrm{H}_{0}$ \\
\hline $\mathrm{Y} 3 \sim \mathrm{X} 1+\mathrm{X} 2+\mathrm{X} 3+\mathrm{Y} 1$ & 0.7126 & Accept $\mathrm{H}_{0}$ \\
\hline
\end{tabular}

(Source: processed by researchers, 2021)

Based on the test results, with a significance level of $5 \%$, there is sufficient evidence to state that the structural model 1 , structural model 2, and structural model 3 have no symptoms of heteroscedasticity so that the three models meet the assumption of homoscedasticity.

Based on the assumption test that has been carried out, information is obtained that the assumption of linearity and the assumption of homogeneity of variance of error has been met. However, the assumption of error normality has not been met, so the appropriate analysis is Path analysis with OLS bootstrap approach.

\section{Hypothesis test}

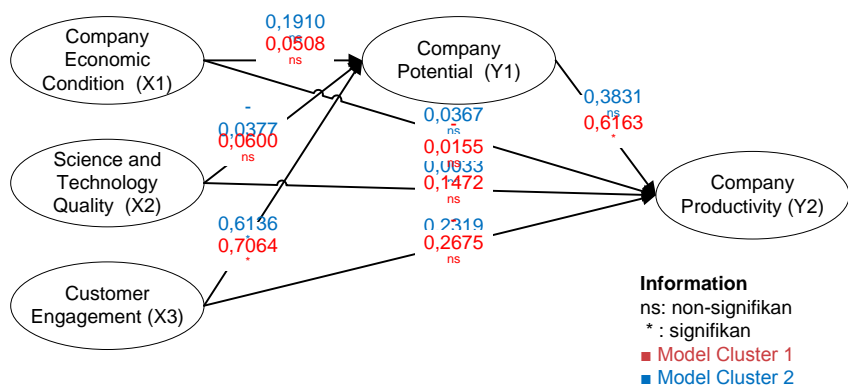

Fig 2. Path Model (Cluster 1 and Cluster 2)

Source: Research Results (2021)

\section{1) Cluster 1 Hypothesis Testing}

The results of hypothesis testing contain path coefficient values and p-values. In Table 5 below, the results of the direct influence hypothesis test are presented.

Table 5. Results of Research Hypothesis Testing

\begin{tabular}{|c|l|l|l|r|r|r|}
\hline No. & \multicolumn{3}{|c|}{ Variable Relationship } & Path Coefficient & P-value & Information \\
\hline 1 & Company Economic Condition (X1) & $\rightarrow$ & Company Potential (Y1) & 0.0508 & 0.6460 & Not significant \\
\hline 2 & Science and Technology Quality (X2) & $\rightarrow$ & Company Potential (Y1) & 0.0600 & 0.5830 & Not significant \\
\hline 3 & Customer Engagement (X3) & $\rightarrow$ & Company Potential (Y1) & 0.7064 & 0.0000 & Significant \\
\hline 4 & Company Economic Condition (X1) & & Company Productivity (Y2) & -0.0155 & 0.9154 & Not significant \\
\hline 5 & Science and Technology Quality (X2) & $\rightarrow$ & Company Productivity (Y2) & 0.1472 & 0.3038 & Not significant \\
\hline 6 & Customer Engagement (X3) & $\rightarrow$ & Company Productivity (Y2) & -0.2675 & 0.2364 \\
\hline 7 & Company Potential (Y1) & $\rightarrow$ & Company Productivity (Y2) & & 0.6163 & 0.0098 \\
\hline
\end{tabular}

Source: Primary Data Processed, 2021

\section{i. Company Economic Condition (XI) Towards Company Potential (Y1)}

Based on Table 5, the effect of the Company's Economic Condition (X1) on the Company's Potential (Y1) is known to have a path coefficient of 0.0508 with $p$-value $=0.6460$. A positive path coefficient indicates that there is a positive effect of the Company's Economic Condition (X1) on the Company's Potential (Y1). Meanwhile, a p-value of more than 0.05 indicates that there is no significant effect. Thus it can be said that Hypothesis 1 is rejected. The Company's Economic Condition (X1) cannot significantly and positively affect the Company's Potential (Y1). PT Pelindo II customers consider that the economic condition of PT Pelindo II is good. The good economic condition of the PT Pelindo II company is also reflected by the suitability of port ticket prices, the company's economic problems, the company's cooperation, activeness in conducting business innovations, increasing cooperation, and the growth of the flow of goods. Good economic conditions are very much needed by PT Pelindo II in continuing the

company's operations. The potential of PT Plindo II is quite good.

\section{ii. Science and Technology Quality (X2) Towards Company Potential (Y1)}

Based on Table 5, the influence of the Quality of Science and Technology (X2) on the Company's Potential (Y1) is known to have a path coefficient of 0.0600 with $\mathrm{p}$-value $=$ 0.5830 . A positive path coefficient indicates that there is a positive influence of the Quality of Science and Technology (X2) on the Company's Potential (Y1). Meanwhile, a p-value of more than 0.05 indicates that there is no significant effect. Thus it can be said that Hypothesis 2 is rejected. The quality of science and technology (X2) cannot affect the Company's Potential (Y1) significantly and positively. 
PT Pelindo II customers consider that the quality of PT Pelindo II's science and technology is quite good. The good quality of PT Pelindo II's science and technology is also reflected by the use of technology in the company, the availability of technology in the company, the ability of employees to master technology, the convenience of using technology, the function of technology, and the development of science and technology. The potential of PT Plindo II is quite good. However, the level of goodness from the potential of the PT Pelindo II port is not as high as the goodness of the quality of science and technology. This shows that when PT Pelindo II's science and technology quality is good, it does not automatically increase the company's potential.

\section{iii. Customer Engagement (X3) Towards Company Potential (Y1)}

Based on Table 5, the effect of Customer Engagement (X3) on Company Potential (Y1) is known to have a path coefficient of 0.7064 with $p$-value $<0.001$. A positive path coefficient indicates that there is a positive effect of Customer Engagement (X3) on Company Potential (Y1). Meanwhile, the p-value less than 0.05 indicates a significant effect. Thus it can be said that Hypothesis 3 is accepted. Customer Engagement (X3) can affect the Company's Potential (Y1) significantly and positively. This means that the higher the engagement between customers, the higher the potential of the company.

PT Pelindo II's customer engagement is high. PT Pelindo II's high customer engagement is also reflected by Selfcompany Connection, Company Behavior, Customer Behavior, Brand Characteristics, Company Characteristics, Consumer-Brand Characteristics. The potential of PT Plindo II is quite good. Although the company's potential is in the medium category, this is supported by descriptive results which show that PT Pelindo II's customer engagement is in the high category.

\section{iv. Company Economic Condition (X1) Towards Company Productivity (Y2)}

Based on Table 5, the effect of the Company's Economic Condition (X1) on the Company's Productivity (Y3) is known to have a path coefficient of -0.0155 with $p$-value $=0.9154$. The negative path coefficient indicates that there is a negative effect of the Company's Economic Condition (X1) on the Company's Productivity (Y3). Meanwhile, a p-value of more than 0.05 indicates an insignificant effect. Thus it can be said that Hypothesis 5 is rejected. The Company's Economic Condition (X1) cannot significantly and negatively affect the Company's Productivity (Y3).

PT Pelindo II customers consider that the economic condition of PT Pelindo II is good. The good economic condition of the PT Pelindo II company is also reflected by the suitability of port ticket prices, the company's economic problems, the company's cooperation, activeness in conducting business innovations, increasing cooperation, and the growth of the flow of goods. The productivity of PT Plindo II is quite good. Although the economic condition of the company and the productivity of the company are equally good, the effect of the company's economic condition on the productivity of the company is not significant.

\section{v. Science and Technology Quality (X2) Towards Company \\ Productivity (Y2)}

Based on Table 5, the effect of Science and Technology Quality (X2) on Company Productivity (Y3) is known to have a path coefficient of 0.1472 with $p$-value $=0.3038$. A positive path coefficient indicates that there is a positive influence of the quality of science and technology (X2) on the company's productivity (Y3). However, the p-value is more than 0.05 which indicates that there is no significant effect. Thus it can be said that Hypothesis 6 is rejected. The quality of science and technology (X2) cannot significantly and positively affect the Company's Productivity (Y3).

PT Pelindo II customers consider that the quality of PT Pelindo II's science and technology is quite good. The good quality of PT Pelindo II's science and technology is also reflected by the use of technology in the company, the availability of technology in the company, the ability of employees to master technology, the convenience of using technology, the function of technology, and the development of science and technology. Good quality of science and technology is needed by PT Pelindo II in facing technological developments in the era of the industrial revolution 4.0 which is believed to be able to improve quality and is predicted to be able to make social changes from a business perspective. The productivity of PT Plindo II is quite good. Although the condition of the quality of science and technology and company productivity is equally good, the influence of the quality of the company's science and technology on company productivity is not significant. This happens because the high productivity of the company is not only influenced by the quality of the company's science and technology but there are other factors.

\section{vi. Customer Engagement (X3) Towards Company Productivity (Y2)}

Based on Table 5, the effect of Customer Engagement (X3) on Company Productivity (Y3) is known to have a path coefficient of -0.2675 with $\mathrm{p}$-value $=0.2364$. A negative path coefficient indicates that there is a negative effect of Customer Engagement (X3) on Company Productivity (Y3). Meanwhile, a p-value of more than 0.05 indicates that there is no significant effect. Thus it can be said that Hypothesis 7 is rejected. Customer Engagement (X3) cannot significantly and negatively affect Customer Engagement (X3).

PT Pelindo II's customer engagement is high. PT Pelindo II's high customer engagement is also reflected by Self-company Connection, Company Behavior, Customer Behavior, Brand Characteristics, Company Characteristics, Consumer-Brand Characteristics. High customer engagement is needed by PT Pelindo II in business progress. Where high engagement is believed to increase the marketing of PT Pelindo II.

\section{vii. Company Potential (Y1) Towards Company Productivity (Y2)}

Based on Table 5, the effect of Firm Potential (Y1) on Firm Productivity (Y3) is known to have a path coefficient of 0.6163 with $\mathrm{p}$-value $=0.0098$. A positive path coefficient indicates that there is a positive effect of Company Potential 
(Y1) on Company Productivity (Y3). Meanwhile, a p-value of more than 0.05 indicates a significant effect. Thus it can be said that Hypothesis 8 is accepted. The company's potential (Y1) can affect the company's productivity (Y3) significantly and positively. This means that the higher the company's potential, the higher the company's productivity.

The potential of PT Pelindo II is quite good. The company's potential is reflected by the number of company branches, the development of company branches, the number of consumers, the presence of investors, increased profits, potential to be an alternative. The better the potential of PT Pelindo II, the greater the chance for the company to be sustainable. Customers consider that the productivity of PT Pelindo II is quite good. This is supported by descriptive results which state that the potential of PT Pelindo II is also quite good. This shows that the better the potential of the PT Plindo II company, the higher the productivity of the PT Pelindo II company.

\section{2) Cluster 2 Hypothesis Testing}

The results of hypothesis testing contain path coefficient values and $p$-values. In Table 6 below, the results of the direct influence hypothesis test are presented.

Table 6. Research Hypothesis Testing Results

\begin{tabular}{|c|l|l|l|c|c|l|}
\hline No. & \multicolumn{3}{|c|}{ Variable Relationship } & $\begin{array}{c}\text { Path } \\
\text { Coeffic } \\
\text { ient }\end{array}$ & $\begin{array}{c}\text { P- } \\
\text { val } \\
\text { ue }\end{array}$ & $\begin{array}{l}\text { Infor } \\
\text { matio } \\
\text { n }\end{array}$ \\
\hline 1 & $\begin{array}{l}\text { Company } \\
\text { Economic } \\
\text { Condition (X1) }\end{array}$ & $\rightarrow$ & $\begin{array}{l}\text { Company } \\
\text { Potential } \\
\text { (Y1) }\end{array}$ & 0.1910 & $\begin{array}{r}0.1 \\
927\end{array}$ & $\begin{array}{l}\text { Not } \\
\text { signif } \\
\text { icant }\end{array}$ \\
\hline 2 & $\begin{array}{l}\text { Science and } \\
\text { Technology } \\
\text { Quality (X2) }\end{array}$ & $\rightarrow$ & $\begin{array}{l}\text { Company } \\
\text { Potential } \\
\text { (Y1) }\end{array}$ & -0.0377 & 0.7 & $\begin{array}{l}\text { Not } \\
\text { signif } \\
\text { icant }\end{array}$ \\
\hline 3 & $\begin{array}{l}\text { Customer } \\
\text { Engagement } \\
\text { (X3) }\end{array}$ & $\rightarrow$ & $\begin{array}{l}\text { Company } \\
\text { Potential } \\
\text { (Y1) }\end{array}$ & 0.6136 & 0.0 & $\begin{array}{l}\text { Signif } \\
\text { icant }\end{array}$ \\
\hline 4 & $\begin{array}{l}\text { Company } \\
\text { Economic } \\
\text { Condition (X1) }\end{array}$ & $\rightarrow$ & $\begin{array}{l}\text { Company } \\
\text { Productiv } \\
\text { ity (Y2) }\end{array}$ & 0.0367 & 0.8 & $\begin{array}{l}\text { Not } \\
\text { signif } \\
\text { icant }\end{array}$ \\
\hline 5 & $\begin{array}{l}\text { Science and } \\
\text { Technology } \\
\text { Quality (X2) }\end{array}$ & $\rightarrow$ & $\begin{array}{l}\text { Company } \\
\text { Productiv } \\
\text { ity (Y2) }\end{array}$ & 0.0033 & 0.9 & $\begin{array}{l}\text { Not } \\
\text { signif } \\
\text { icant }\end{array}$ \\
\hline 6 & $\begin{array}{l}\text { Customer } \\
\text { Engagement } \\
\text { (X3) }\end{array}$ & $\rightarrow$ & $\begin{array}{l}\text { Company } \\
\text { Productiv } \\
\text { ity (Y2) }\end{array}$ & -0.2319 & 0.4 & $\begin{array}{l}\text { Not } \\
\text { signif } \\
\text { icant }\end{array}$ \\
\hline 7 & $\begin{array}{l}\text { Company } \\
\text { Potential (Y1) }\end{array}$ & $\rightarrow$ & $\begin{array}{l}\text { Company } \\
\text { Productiv } \\
\text { ity (Y2) }\end{array}$ & 0.3831 & 0.1 & $\begin{array}{l}\text { Not } \\
\text { signif } \\
\text { icant }\end{array}$ \\
\hline
\end{tabular}

Source: Primary Data Processed, 2021

\section{i. Company Economic Condition (X1) Towards Company Potential (Y1)}

Based on Table 6, the effect of the Company's Economic Condition (X1) on the Company's Potential (Y1) is known to have a path coefficient of 0.1910 with $p$-value $=0.1927$. A positive path coefficient indicates that there is a positive effect of the Company's Economic Condition (X1) on the Company's Potential (Y1). Meanwhile, a p-value of more than 0.05 indicates that there is no significant effect. Thus it can be said that Hypothesis 1 is rejected. The Company's Economic
Condition (X1) cannot significantly and positively affect the Company's Potential (Y1).

PT Pelindo II customers consider that the economic condition of PT Pelindo II is good. The good economic condition of the PT Pelindo II company is also reflected by the suitability of port ticket prices, the company's economic problems, the company's cooperation, activeness in conducting business innovations, increasing cooperation, and the growth of the flow of goods. Good economic conditions are very much needed by PT Pelindo II in continuing the company's operations. Where good economic conditions are believed to improve quality in terms of business. The potential of PT Plindo II is quite good. Although the company's economic conditions and company potential are in the good category, the influence of the company's economic conditions on the company's potential is not significant. This shows that when the economic condition of the PT Pelindo II company is good, it does not automatically increase the company's potential.

\section{ii. Science and Technology Quality (X2) Towards Company Potential (Y1)}

Based on Table 6, the influence of Science and Technology Quality (X2) on Company Potential (Y1) is known to have a path coefficient of -0.0377 with $\mathrm{p}$-value $=0.7963$. The negative path coefficient indicates that there is a negative effect of the Quality of Science and Technology (X2) on the Company's Potential (Y1). Meanwhile, a p-value of more than 0.05 indicates that there is no significant effect. Thus it can be said that Hypothesis 2 is rejected. The quality of science and technology (X2) can affect the company's potential (Y1) in an insignificant and negative way.

PT Pelindo II customers consider that the quality of PT Pelindo II's science and technology is good. The good quality of PT Pelindo II's science and technology is also reflected by the use of technology in the company, the availability of technology in the company, the ability of employees to master technology, the convenience of using technology, the function of technology, and the development of science and technology. Good quality of science and technology is needed by PT Pelindo II in facing technological developments in the era of the industrial revolution 4.0 which is believed to be able to improve quality and is predicted to be able to make social changes from a business perspective. The quality of science and technology must evolve following the existing era. The potential of PT Plindo II is quite good. Although the quality of the company's science and technology and the company's potential are in the good category, the influence of the company's science and technology quality on the company's potential is not significant. This shows that when PT Pelindo II's science and technology quality is good, it does not automatically increase the company's potential.

\section{iii. Customer Engagement (X3) Towards Company Potential (Y1)}

Based on Table 6, the effect of Customer Engagement (X3) on Company Potential (Y1) is known to have a path coefficient of 0.6136 with $\mathrm{p}$-value $<0.001$. A positive path coefficient indicates that there is a positive effect of Customer Engagement (X3) on Company Potential (Y1). Meanwhile, a 
p-value of less than 0.05 indicates a significant effect. Thus it can be said that Hypothesis 3 is accepted. Customer Engagement (X3) can affect the Company's Potential (Y1) significantly and positively. This means that the higher the engagement between customers, the higher the potential of the company.

PT Pelindo II's customer engagement is high. PT Pelindo II's high customer engagement is also reflected by Selfcompany Connection, Company Behavior, Customer Behavior, Brand Characteristics, Company Characteristics, Consumer-Brand Characteristics. High customer engagement is needed by PT Pelindo II in business progress. Where high engagement is believed to increase the marketing of PT Pelindo II. In the future, it is hoped that PT Pelindo II can continue to increase customer engagement. The potential of PT Plindo II is quite good. This is supported by descriptive results which show that PT Pelindo II's customer engagement is in the high category. Based on the hypothesis test conducted, it is found that customer engagement has a significant effect on the company's potential, where the higher customer engagement will increase the company's potential. This is indeed appropriate that when a company's customer engagement is high, the company will gain a wide market share which causes the company's profit to be large which of course will increase the company's potential to develop further.

\section{iv. Company Economic Condition (X1) Towards Company Productivity (Y2)}

Based on Table 6, the effect of the Company's Economic Condition (X1) on the Company's Productivity (Y2) is known to have a path coefficient of 0.0367 with p-value $=0.8450$. The negative path coefficient indicates that there is a negative effect of the Company's Economic Condition (X1) on the Company's Productivity (Y3). Meanwhile, a p-value of more than 0.05 indicates that there is no significant effect. Thus it can be said that Hypothesis 5 is rejected. The Company's Economic Condition (X1) can affect the Company's Productivity (Y3) insignificantly and negatively.

PT Pelindo II customers consider that the economic condition of PT Pelindo II is good. The good economic condition of the PT Pelindo II company is also reflected by the suitability of port ticket prices, the company's economic problems, the company's cooperation, activeness in conducting business innovations, increasing cooperation, and the growth of the flow of goods. Good economic conditions are very much needed by PT Pelindo II in continuing the company's operations. Where good economic conditions are believed to improve quality in terms of business. The productivity of PT Plindo II is quite good. Although the economic condition of the company and the productivity of the company are equally good, the effect of the company's economic condition on the productivity of the company is not significant. This happens because the high productivity of the company is not only influenced by the company's economic conditions but there are other factors.

\section{v. Science and Technology Quality (X2) Towards Company Productivity (Y2)}

Based on Table 6, the effect of Science and Technology Quality (X2) on Company Productivity (Y2) is known to have a path coefficient of 0.0033 with $p$-value $=0.9860$. A positive path coefficient indicates that there is a positive influence of the quality of science and technology (X2) on the company's productivity (Y3). However, the p-value is more than 0.05 which indicates that there is no significant effect. Thus it can be said that Hypothesis 6 is rejected. The quality of science and technology (X2) cannot significantly and positively affect the Company's Productivity (Y3).

PT Pelindo II customers consider that the quality of PT Pelindo II's science and technology is good. The good quality of PT Pelindo II's science and technology is also reflected by the use of technology in the company, the availability of technology in the company, the ability of employees to master technology, the convenience of using technology, the function of technology, and the development of science and technology. Good quality of science and technology is needed by PT Pelindo II in facing technological developments in the era of the industrial revolution 4.0 which is believed to be able to improve quality and is predicted to be able to make social changes from a business perspective. The productivity of PT Plindo II is quite good. Although the condition of the quality of science and technology and company productivity is equally good, the influence of the quality of the company's science and technology on company productivity is not significant. This happens because the high productivity of the company is not only influenced by the quality of the company's science and technology but there are other factors.

\section{vi. Customer Engagement (X3) Towards Company Productivity (Y2)}

Based on Table 6, the effect of Customer Engagement (X3) on Company Productivity (Y2) is known to have a path coefficient of -0.2319 with $p$-value $=0.4210$. A negative path coefficient indicates that there is a negative effect of Customer Engagement (X3) on Company Productivity (Y3). Meanwhile, a p-value of more than 0.05 indicates that there is no significant effect. Thus it can be said that Hypothesis 7 is rejected. Customer Engagement (X3) cannot significantly and negatively affect Customer Engagement (X3).

PT Pelindo II's customer engagement is high. PT Pelindo II's high customer engagement is also reflected by Selfcompany Connection, Company Behavior, Customer Behavior, Brand Characteristics, Company Characteristics, Consumer-Brand Characteristics. High customer engagement is needed by PT Pelindo II in business progress. Where high engagement is believed to increase the marketing of PT Pelindo II. The productivity of PT Plindo II is quite good. Although customer engagement and company productivity are equally good, the effect of PT Pelindo II's customer engagement on PT Pelindo II's company productivity is not significant. This happens because the high productivity of the company is not only influenced by the quality of the company's science and technology but there are other factors. 
vii. Towards Company Potential (Y1) Towards Company Productivity (Y2)

Based on Table 6, the effect of Firm Potential (Y1) on Firm Productivity (Y2) is known to have a path coefficient of 0.3831 with $\mathrm{p}$-value $=0.1120$. A positive path coefficient indicates that there is a positive effect of Company Potential (Y1) on Company Productivity (Y3). Meanwhile, a p-value of more than 0.05 indicates that there is no significant effect. Thus it can be said that Hypothesis 8 is rejected. The company's potential (Y1) can not affect the company's productivity (Y3) significantly and positively.

The potential of PT Pelindo II is quite good. The company's potential is reflected by the number of company branches, the development of company branches, the number of consumers, the presence of investors, increased profits, potential to be an alternative. The better the potential of PT Pelindo II, the greater the chance for the company to be sustainable. Customers consider that the productivity of PT Pelindo II is quite good. Although the company's potential and productivity of PT Pelindo II are both high, based on the hypothesis test, it is found that the company's potential has not been able to significantly increase the company's productivity.

\section{CONCLUSIONS AND RECOMMENDATIONS}

Path analysis in Cluster 1 and Cluster 1 shows that from nine direct effect tests, it was found that 2 effects gave significant results and the rest did not give significant effects. The significant effect is the influence of Customer Engagement (X3) on Company Potential (Y1). The coefficient of determination of the total path analysis in Cluster 1 is 0.8235 or $82.35 \%$, while in Cluster 2 it is 0.7421 or $74.21 \%$. In cluster 1 , there is one significant relationship, namely the company potential variable on company production. However, in cluster 2 there is no significant relationship. So it is recommended that $\mathrm{PT}$ Pelindo II pay more attention to company potential in cluster 1 in order to be able to increase company production.

\section{ACKNOWLEDGMENT}

This paper has a contribution to science, namely the development of cluster analysis that can be integrated into Path analysis.

\section{REFERENCES}

[1] Gujarati, D. N., \& Porter, D. C. 2012. Dasar-Dasar Ekonometrika, Edisi 5. Jakarta: Salemba Empat. Kutner, M. H., Nachtsheim, C. J., Neter, J., \& Li, W. 2005. Applied linear statistical models (Vol. 5). New York: McGraw-Hill Irwin.

[2] Solimun and Fernandes, A.A.R. (2017), Investigation the mediating variable: What is necessary? (case study in management research), International Journal of Law and Management, 59(6), 1059-1067. https://doi.org/10.1108/IJLMA-09-2016-0077
[3] MacLean, S., \& Gray, K. (1998). Structural equation modelling in market research. Journal of the Australian market research society, 6(1), 17-32.

[4] Kutner, M. H., Nachtsheim, C. J., Neter, J., \& Li, W.. Applied linear statistical models. 2005. New York: McGraw-Hill Irwin.

[5] Irwan, I., \& Adam, K. (2015). Metode partial least square (PLS) dan terapannya (Studi kasus: analisis kepuasan pelanggan terhadap layanan PDAM unit camming kab. Bone). Teknosains: Media Informasi Sains dan Teknologi, 9(1), 53-68.

[6] Fernandes, A. A. R., Budiantara, I. N. I., Otok, B. W., \& Suhartono. (2014). Reproducing Kernel Hilbert space for penalized regression multi-predictors: Case in longitudinal data. International Journal of Mathematical Analysis, 8(40), 1951-1961.

[7] Fernandes, A. A. R. and Solimun. (2017). Moderating effects orientation and innovation strategy on the effect of uncertainty on the performance of business environment. International Journal of Law and Management, 59(6), 1211-1219. https://doi.org/10.1108/IJLMA-10-2016-0088

[8] Li, C. C. Path Analysis-a primer. 1975. California: The Boxwood Press.

[9] Himawan, K. W. (2017). Pendekatan WarpPLS Pada Pemodelan Persamaan Struktural Nilai Perusahaan Real Estate Yang Terdaftar Di BEI (Doctoral dissertation, Universitas Brawijaya).

[10] Sumardi, S. and Fernandes, A.A.R. (2018). The mediating effect of service quality and organizational commitment on the effect of management process alignment on higher education performance in Makassar, Indonesia. Journal of Organizational Change Management, 31(2), 410-425. https://doi.org/10.1108/JOCM-11-2016-0247

[11] Johnson, R. A. dan Wichern, D. W. Applied Multivariate. Analysis. 1992. Upper Saddle River, NJ: Prentice Hall.

[12] Fernandes, A. A. R., Hutahayan, B., Arisoesilaningsih, E., Yanti, I., Astuti, A. B., \& Amaliana, L. (2019, June). Comparison of Curve Estimation of the Smoothing Spline Nonparametric Function Path Based on PLS and PWLS In Various Levels of Heteroscedasticity. In IOP Conference Series: Materials Science and Engineering (Vol. 546, No. 5, p. 052024). IOP Publishing.

[13] Eubank, R. L. Nonparametric regression and spline smoothing. CRC press. 1999.

\section{Creative Commons Attribution License $\mathbf{4 . 0}$ (Attribution 4.0 International, CC BY 4.0)}

This article is published under the terms of the Creative Commons Attribution License 4.0

https://creativecommons.org/licenses/by/4.0/deed.en_US 